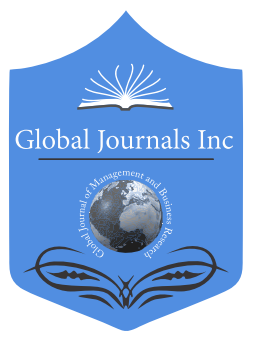

\title{
Analysis of Monetary Policy, Capital, Saving, FDI, and Economic Development for High and Middle Income Economies with ARDL Approach
}

By Qamar Rasheed

The University of Lahore

Abstract- Monetary policy and macroeconomic factors play a decisive and fascinating role to determine the economic output of the country. Policymakers and economists take very seriously and consider them deterministic because these factors have an influence on each other. Therefore, the research has the objective to delineate the effect of monetary policy and all given indicators together on economic development precisely and their interdependence as well. ARDL (Autoregressive Distributed Lag) Bounds test cointegration technique is applied by employing annual time series data from 1980 to 2018. Money supply, lending interest rate, inflation, capital, saving, FDI, and economic development are said to be independent variables and explanatory variables one by one for each country separately to ascertain their interdependence.

Keywords: monetary policy, capital, savings, foreign direct investment, economic development, ARDL (Autoregressive Distributed Lag), ECM mechanism, and granger causality.

GJMBR-B Classification: JEL Code: F63

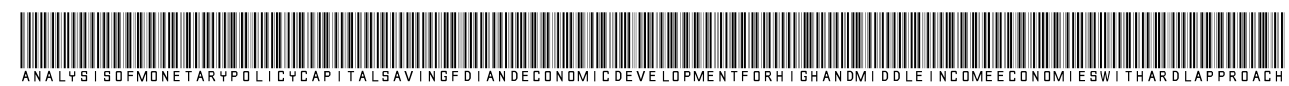

Strictly as per the compliance and regulations of:

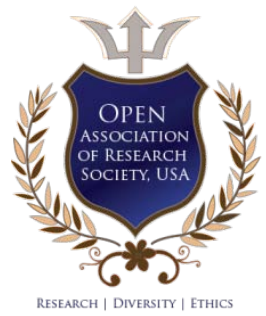

(C) 2020. Qamar Rasheed. This is a research/review paper, distributed under the terms of the Creative Commons AttributionNoncommercial 3.0 Unported License http://creativecommons.org/licenses/by-nc/3.0/), permitting all non-commercial use, distribution, and reproduction in any medium, provided the original work is properly cited. 


\title{
Analysis of Monetary Policy, Capital, Saving, FDI, and Economic Development for High and Middle Income Economies with ARDL Approach
}

\author{
Qamar Rasheed
}

\begin{abstract}
Monetary policy and macroeconomic factors play a decisive and fascinating role to determine the economic output of the country. Policymakers and economists take very seriously and consider them deterministic because these factors have an influence on each other. Therefore, the research has the objective to delineate the effect of monetary policy and all given indicators together on economic development precisely and their interdependence as well. ARDL (Autoregressive Distributed Lag) Bounds test cointegration technique is applied by employing annual time series data from 1980 to 2018 . Money supply, lending interest rate, inflation, capital, saving, $\mathrm{FDI}$, and economic development are said to be independent variables and explanatory variables one by one for each country separately to ascertain their interdependence. The study is conducted about Singapore and South Korea as high-income economies, whereas Malaysia and Thailand are considered as middle-income economies. The result of the long run effect is achieved by the ARDL bounds test approach and ECM (Error Correction Model). The optimum lag is selected through VAR (Vector auto regression), the data is made through residual diagnostics like normality test, serial correlation LM test, and heteroskedasticity test.
\end{abstract}

High-income economies may face a deteriorating situation during the volatility of the study's negotiating factors as compared to middle-income economies. Gross savings and lending interest rates may cause significant fluctuations in comparatively other participating economic indicators in Singapore and South Korea. Similarly, gross capital formation and GDP per capita may cause volatility in other study's variables relative to other economic determinants of the study. Conclusively, all economic factors of the study may jointly affect the individual variable in each case of the study.

The Granger Causality test is performed to make sure the unidirectional causality, bidirectional causality and nondirectional causality between regressor and regressand. Mostly variables have bidirectional causation and few of them have unidirectional causation as per Pairwise Granger Causality Tests results.

Keywords: monetary policy, capital, savings, foreign direct investment, economic development, ARDL (Autoregressive Distributed Lag), ECM mechanism, and granger causality.

Author: M. Phil. Finance, The University of Lahore, School of Accountancy and Finance, Lahore, Pakistan.

e-mail: qamarali1989@yahoo.com

\section{INTRODUCTION}

1 onetary policy is defined as the policy adopted by the central bank to control the money supply and interest rate in the country as per the definition of Handa (2009). The central bank of the country deals with the monetary policy with the help of different financial instruments like interest rates and inflation. Interest rate, inflation, and money supply play the main role to keep the well-balanced financial market and overall prices. Monetary policy secures money supply stability and helps to obtain fuller utilization of economic resources. It is necessary to sustain and keep it restricted range to get desirable results. According to Measuring Capital OECD Manual 2009, the money supply is one of the core factors to determine economic development. Gross fixed capital formation is defined as obtain and less salvages of fixed assets including plant, machinery, tools, and equipment including substantial improvement on non- produced assets. The assets procured can be new or they can be used or second hand. UNCTAD is defined that foreign direct investment describes as the investor has a long term business relationship and has significant influence on the management of the host country whereas it is controlled by the resident country. Individuals and business entities may be incorporated in FDI. Organization for Economic Co-operation and Development clarified that gross saving is the difference between disposable income and final consumption plus net transfers. The low saving rate affects the current account deficit and makes the worse international investment. Ayyoub et al. (2011) founded, when inflation exceeds its particular level, which makes trouble for the economy due to an increase in the average price level of the goods, and services, therefore, policymakers need to contemplate another option to keep inflation stable and moderate. Money supply also helpful to reduce the uncertainties to boost capital formations in the country. Chang et al. (2014) appreciated the Chinese monetary policy, which has proved inflation management because china has been dealing vigorously with business activities and monetary policy for the last two decades. Nguyen (2015) described a low rate of inflation is one of the finest objectives of macroeconomic practice and price stability plays a beneficial role in the determination of economic 
development. Chaitip et al. (2015) suggested that monetary policy manipulates GDP growth, inflation rate and, exchange rate so it uses as an economic tool to maintain and promote economic progress. Mansur (2011) described that government needs to introduce strategies to make a rapid contribution to export and inflow of foreign capital. In the new global arena, there is a need for trade liberalization policies to organize savings and investment. That is why the government has been taking aggressive steps to make sure domestic demand and enhance economic growth. Taspinar (2014) stated that foreign direct investment and domestic savings raise the real income of the country. Mousavi and Monjazeb (2014) expressed that saving is the most important macroeconomic indicator for the country to utilize the financial and capital resource, which is taken into consideration for the determination of the level of investment in the country. Turan and Gjergji (2014) mentioned that the government needs to give special attention to make policies to attract foreign direct investment, which may intensify savings and encourage economic growth as well. Akram (2015) demonstrated the benefits of savings for a country because it causes the financial sector to grow and control inflation. Alvi and Fatima (2017) described that domestic savings play a vital role in economic development and as well as promoting capital. Saving and interest rates could effectively control inflation and money supply in the short run but that cannot happen in the long run. Bhat and Laskar (2016) endorsed that efficient monetary policies will help in balancing and steadying inflation and interest rate to improve economic growth. Shaukat et al. (2019) intimated that the low interest rate is productive for developing countries to attain and sustain higher economic growth.

\section{il. Literature Review}

\section{a) Monetary Policy and Economic Development}

Ayyoub et al. (2011) employed Ordinary Least Square to analyze the relationship between inflation level and economic growth for annual time series data from 1972 to 2010 in Pakistan. They found that after a certain level of inflation, the economy was beginning to fall into the danger zone and inflation has to be kept below the $7 \%$ rate to run an economy smoothly. Jiang and Chang (2014) examined the interdependence of money growth and inflation in China with the help of monthly data span from January 1991 to June 2014. They transformed original data into natural logs and taken the first difference to adjust seasonal trends within the time series. They got different time scale with the help of wavelet analysis to draw conclusion. They found that money growth and inflation linked positively in the longrun while discovered some divergence in the short run because of temporary fluctuations. Nguyen (2015) probed money supply and fiscal deficit on inflation nine selected Asian economies for 28 years. The data was taken from the Asian Development Bank for eight variables from 1985 to 2012. The study was used inflation, fiscal deficit, money supply, GDP per capita, government expenditure, exchange rate, trade openness, and interest rate. The study found the positive relationship between money supply and inflation based on pooled mean group method of analysis while interest rate, government expenditure, and fiscal deficit were significantly affecting inflation as per GMM and PMG method of analysis. Chaitip et al. (2015) applied the Pooled Mean Group and Mean Group under panel ARDL model to examine the long run and short run association of eight Asian countries to show the influence of money supply on economic growth for 19 years. The research concluded that there is a long run relationship between money supply and economic growth. Nizhegorodtsev and Goridko (2015) revealed the nonlinear relationship between GDP growth and money supply by performing macroeconomic equilibrium in the money of real goods and money market. The study was consisted on five BRICS countries, G7 countries, five PIIGS countries, some European and Asian countries as well. Urbanovsky (2016) showed the interaction of monetary policy, price level interest rate and real GDP by applying VAR (Vector autoregression) approach and Granger Causality test. The study suggested that the price level has influence on interest rate whereas interest rate and price level both could affect the real GDP. Morteza and Farahani (2016) found that the negative effects of monetary policy have more impact on production growth than positive effects in the same period because organizations do not change their price level. They do not try to decrease the price level due to having some hesitation. The study ratified that countries depend on natural resources need to change the price in the long-run because of market structure. However, they do not need to make changes in the short run. The study used a vector error correction model (VECM) to draw the conclusion about money supply and economic activity. Bhat and Laskar (2016) found that GDP behaves negatively against the interest rate while it behaves positively against inflation rate in Indian perspective. Anwar et al. (2016) used OLS (Ordinary Least Square) approach to test the function of monetary policy, inflation rate, exchange rate and interest rate, and economic growth of Pakistan quarterly basis from 1972 to 2011. GDP behaved insignificantly against money supply and inflation rate whereas interest rate and exchange rate have a significant influence on GDP. Sasongko and Huruta (2018) showed that there is a one-way causality between money supply and inflation in Indonesia. Denbel et al. (2016) disclosed that economic growth affected by the change of money supply and inflation based on the VECM approach. The study concluded that the unidirectional causal relationship existed between economic growth and 
inflation rate as per the Granger Causality test. Twinoburyo and Odhiambo (2018) carried out a survey of prevailing theoretical and recent empirical findings to know the effect of monetary policy on economic growth. They described that most of the previous research has been supporting the role of monetary policy on the economy. However, the strength of influence is different in developing and developed economies because of the control of the central bank to make policies. Sahin and Dogan (2017) organized a study on the United States economy for 58 years from 1959 to 2016 to ascertain the neutrality of money. The study utilized the EGARCH model, ADCC-EGARCH (Asymmetric Dynamic Conditional Correlation) model, and Detrended Cross Correlation (DCCA) model to discover the short run and the long relationship respectively between money supply and economic output. The results of the study indicated a positive simultaneous long-run association between money supply and economic output in levels as per the DCCA approach. Bukowski and Bukowska (2017) discovered with the help of the VAR model that the euro area needs to make a strong interest rate policy for effective economic growth. Hussain and Zafar (2018) applied ARDL Bounds Testing and ECM model to analyze the short run and the long run relationship between inflation, money supply, public expenditure, and economic growth. The research discovered long run relationship between fiscal policy, inflation and economic growth while bidirectional causality seemed between money supply, inflation, and fiscal policies. Mele and Stefanski (2019) conducted a research from 1980 to 2010 of 102 counties to reveal the influence of money demand and price level. The research found that the cost of poor monetary policy is less in poor countries than rich countries. Many studies have explored affirmative connection between monetary policy and economic output such as Mlosa et al. (2014), Mansoor et al. (2018), Tiryaki et al. (2018), Tsai and Chang (2018), Aslam (2016), Galadima and Ngada (2017), Leea and Werner (2018), and Celik et al. (2019). Moreover, Jednak and Kraguli (2018) found an insignificant relationship between inflation and economic growth in Serbia and Poland from 1991 to 2016.

\section{b) Savings, Capital, Foreign Direct Investment and Economic Development}

Mansur (2011) analyzed the contribution of savings, investment and foreign direct investment on economic growth to Malaysia. They revealed that the Malaysian economy depends on national level activities because of the uncertainty of external investment. They described that the government has been introducing productive ways for trade liberalization to take advantage of savings and investment to further strengthen the Malaysian economy. Castro et al. (2013) employed different variables to determine the factor behind FDI inflow in Brazil and Mexico. The study used a Vector
Error Correction Model and Vector Autoregressive model to observe the relationship among variables. The study concluded that GDP and trade liberalization or trade openness play a crucial role to attract more investment. Najarzadeh et al. (2014) probed the impact of saving on economic growth in Iran for 38 years from 1972 to 2010 by applying the ARDL model. The results showed that saving has a positive and significant impact on economic growth and Iran needs to increase the level of private savings in the country to support investment. Economic growth and saving both have a mutual and two-way relationship with each other. Taspinar (2014) examined the effect of domestic saving and foreign direct investment on the economic growth of Turkey with the help of the Bound test ARDL model subject to the ECM model. Domestic savings have a positive and significant relationship in the short and longrun relationship with real income growth. A short-term unidirectional causality found from FDI to domestic savings as per the Granger Causality approach. Mousavi and Monjazeb (2014) analyzed panel data of seven developed and twelve developing economies to prove the positive and significant impact of economic growth on savings rates through a fixed- effect model approach. Turan and Gjergji (2014) conducted a study on economic growth and savings in Albania. They found a positive and stable long-run relationship by exercising the Johansen Cointegration Test. Belascu and Horobet (2015) revealed the impact of institutional performance with respect to foreign direct investment in Romania. The study acquired corruption data, government effectiveness, political stability, regulatory quality, rule of law and accountability, etc. to measure positive relationships. They disclosed that the performance of institutional factors plays a magnificent role with each other. Akram and Akram (2015) examined the savings behavior of people from four Muslim and four nonMuslim Asian countries in context to the real interest rate. The study performed a panel unit root test, panel Johansen cointegration test, and Fully Modified Least Square approach to report the positive and significant relationship between saving and real interest rate, however, both variables have an insignificant relationship in Muslim countries. Alvi and Fatima (2017) took the unemployment rate, interest rate, inflation rate, and worker remittances to reveal a relationship with the domestic savings of Pakistan. Domestic savings of Pakistan behaved negatively against interest rate and inflation rate in the long run while it behaved positively in the short run as per the result of Auto Regressive Distributed Lag (ARDL) model. Onyinye et al. (2017) observed the influence of capital formation on the economic growth of Nigeria. The study concluded that capital formation has an insignificant and positive effect on economic growth from 1979 to 2009 in Nigeria based on the outcome of VECM (vector error correction model). Most of the studies found positive and favorable 
outcomes of foreign direct investment for economic development and growth. Svedin and Stage (2016), Lloyd (2017), Siddique et al. (2017), Dkhili and Dhiab (2018), and Comes et al. (2018), however, some of the studies stated negative and mix relationship between foreign direct investment and economic growth (such as Carbonell and Werner (2018), and Belloumi and Alshehry (2018).

Equations:

\section{Methodology and Data}

a) Econometric Model

The following equations have been used in the study to examine the effects of monetary policy, savings, capital, and foreign direct investment and economic development with each other:

$$
\begin{aligned}
& \Delta \text { CAPITAL }_{t}=a_{0}+\sum_{i=0}^{p-1} a_{1 i} \Delta \text { CAPITAL } \\
& t-i \\
& \sum_{i=0}^{q-1} a_{3 i} \Delta F D I_{t-i}+\sum_{i=0}^{q-1} a_{4 i} \Delta a_{2 i} \Delta G D \text { IN }_{t-i}+ \\
& \sum_{i=0}^{q-1} a_{6 i} \Delta \text { MONENON } Y_{t-i}+\sum_{i=0}^{q-1} a_{5 i} \Delta \text { INTEREST }_{t-i}+
\end{aligned}
$$

$\sum_{i=0}^{q-1} a_{4 i}$ IINFLATION LI $i+\sum_{i=0}^{q-1} a_{5 i} \Delta$ INTEREST $_{t-i}+\sum_{i=0}^{q-1} a_{6 i} \Delta$ MONEY $_{t-i}+$ $\sum_{i=0}^{q-1} a_{7 i} \Delta S A V I N G_{t-i}+\phi \mathrm{ECT}_{\mathrm{t}-1}+e_{t}$

$$
\begin{aligned}
& \Delta F D I_{t}=a_{0}+\sum_{i=0}^{p-1} a_{1 i} \Delta F D I_{t-i}+\sum_{i=1}^{q-1} a_{2 i} \Delta G D P_{t-i}+\sum_{i=0}^{q-1} a_{3 i} \Delta C A P I T A L_{t-i}+ \\
& \sum_{i=0}^{q-1} a_{4 i} \Delta I N F L A T I O N_{t-i}+\sum_{i=0}^{q-1} a_{5 i} \Delta I N T E R E S T_{t-i}+\sum_{i=0}^{q-1} a_{6 i} \Delta M O N E Y_{t-i}+ \\
& \sum_{i=0}^{q-1} a_{7 i} \Delta S A V I N G_{t-i}+\operatorname{SECT}_{\mathrm{t}-1}+e_{t}
\end{aligned}
$$

$\triangle I N F L A T I O N_{t}=a_{0}+\sum_{i=0}^{p-1} a_{1 i} \Delta I N F L A T I O N_{t-i}+\sum_{i=1}^{q-1} a_{2 i} \Delta G D P_{t-i}+$ $\sum_{i=0}^{q-1} a_{3 i} \Delta C A P I T A L_{t-i}+\sum_{i=0}^{q-1} a_{4 i} \Delta F D I_{t-i}+\sum_{i=0}^{q-1} a_{5 i} \Delta$ INTEREST $_{t-i}+$ $\sum_{i=0}^{q-1} a_{6 i} \Delta M O N E Y_{t-i}+\sum_{i=0}^{q-1} a_{7 i} \Delta S A V I N G_{t-i}+\phi \mathrm{ECT}_{\mathrm{t}-1}+e_{t}$

$$
\begin{aligned}
& \triangle I N T E R E S T_{t}=a_{0}+\sum_{i=0}^{p-1} a_{1 i} \Delta I N T E R E S T_{t-i}+\sum_{i=1}^{q-1} a_{2 i} \Delta G D P_{t-i}+ \\
& \sum_{i=0}^{q-1} a_{3 i} \Delta \text { CAPITAL } L_{t-i}+\sum_{i=0}^{q-1} a_{4 i} \Delta F D I_{t-i}+\sum_{i=0}^{q-1} a_{5 i} \Delta \text { INFLATION }_{t-i}+ \\
& \sum_{i=0}^{q-1} a_{6 i} \Delta M O N E Y_{t-i}+\sum_{i=0}^{q-1} a_{7 i} \Delta S A V I N G_{t-i}+\phi \mathrm{ECT}_{\mathrm{t}-1}+e_{t}
\end{aligned}
$$

$$
\begin{aligned}
& \triangle M O N E Y_{t}=a_{0}+\sum_{i=0}^{p-1} a_{1 i} \Delta M O N E Y_{t-i}+\sum_{i=1}^{q-1} a_{2 i} \Delta G D P_{t-i}+ \\
& \sum_{i=0}^{q-1} a_{3 i} \Delta \text { CAPITAL } L_{t-i}+\sum_{i=0}^{q-1} a_{4 i} \Delta F D I_{t-i}+\sum_{i=0}^{q-1} a_{5 i} \text { INFLATION }_{t-i}+ \\
& \sum_{i=0}^{q-1} a_{6 i} \Delta I N T E R E S T_{t-i}+\sum_{i=0}^{q-1} a_{7 i} \Delta S A V I N G_{t-i}+\text { QECT }_{\mathrm{t}-1}+e_{t}
\end{aligned}
$$

$\triangle S A V I N G_{t}=a_{0}+\sum_{i=0}^{p-1} a_{1 i} \Delta S A V I N G_{t-i}+\sum_{i=1}^{q-1} a_{2 i} \Delta G D P_{t-i}+$ $\sum_{i=0}^{q-1} a_{3 i} \Delta$ CAPITAL $L_{t-i}+\sum_{i=0}^{q-1} a_{4 i} \Delta$ FDI $_{t-i}+\sum_{i=0}^{q-1} a_{5 i} \Delta$ INFLATION $_{t-i}+$ $\sum_{i=0}^{q-1} a_{6 i} \Delta I N T E R E S T_{t-i}+\sum_{i=0}^{q-1} a_{7 i} \Delta M O N E Y_{t-i}+\operatorname{SECT}_{\mathrm{t}-1}+e_{t}$ 
$\triangle$ represents the first difference operator, ECT is appeared for Error Correction Term to determine the strength of long run relationship between GDP per capita of each country and explanatory variables of each country through the ARDL bounds test approach in equation 1. Besides that, the study also evaluates the effects of other variables in more equations. The " $\phi$ " represents the long run effect of a change in independent variable on dependent variable. The lag order of dependent variable and regressors is represented by $\mathrm{p}$ and $\mathrm{q}$. Each variable considered as the dependent and independent variable to analyze the interaction among them from equation (1) to equation (7). Moreover, a0 representing constant or intercept whereas a1, a2, a3, a4, a5, a6 and a7 signifying coefficient of the variables. The equation has $e_{t}$ which used as the error term.

b) Data

The study used annual data of inflation rate, lending interest rate, money supply, savings, capital, FDI, and GDP per capita for Malaysia, Singapore, South Korea, and Thailand, covering 39 years from 1980 to 2018. The data was obtained from The World Bank and WDI (World Development Indicator). GDP per capita served as the country's economic output in constant LCU (Local Currency Unit) for each country. Money supply measured through broad money at current LCU, Gross Capital Formation at LCU, Gross Savings at LCU, and Foreign Direct Investment at current US Dollar for each selected country. All variables are transformed in natural logarithm form except inflation rate and lending interest rate.

\section{c) Methodology}

The objective of the research is to focus on the interaction of money supply capital, interest, inflation, savings, FDI, and GDP per capita in 02 high-income
Asian economies namely Singapore, South Korea, and 02 middle-income Asian economies namely Malaysia and Thailand. The study is being applied the ARDL bound test approach to know the cointegration to examine the long run relationship between variables. The ARDL methodology was introduced by Pesaran et al. (2001). Usually, the Johansen cointegration approach has been used to develop the long run interaction between certain variables. Variables must be integrated at the same level or order as per its requirements. The long run relationship between the variable cannot be possible if variables are not at the same order. ARDL deals with such problems to get better results by presenting the Bound Test procedure and to determine long run interaction among variables. The optimum lag order of variables is determined before executing the ARDL bounds testing method to cointegration. Moreover, the study conducted a unit root test, normality test, serial correlation LM test, and Heteroskedasticity Test before going to apply ARDL bound test for selected economies. Granger Causality Test is also performed to determine the causation amongst the indicators.

\section{Results}

\section{a) Unit Root Test Results}

The unit root is conducted for each variable to know the stationarity in the time series and to find the level of integration of the series before conducting the cointegration test. The unit root test is used to make sure the validity of the results. All variables are stationary at level "I(0)" and first difference "I(1)" according to Augmented Dickey Fuller test at 05\% level of significance. The outcome of the ADF test is reported the stationarity of variables in table 1 at the intercept, intercept, and trend. The unit root test giving a strong reason for the utilization of ARDL because all variables are stationary at the level and first difference.

Table 1: (Augmented Dickey Fuller) Unit Root Test Results

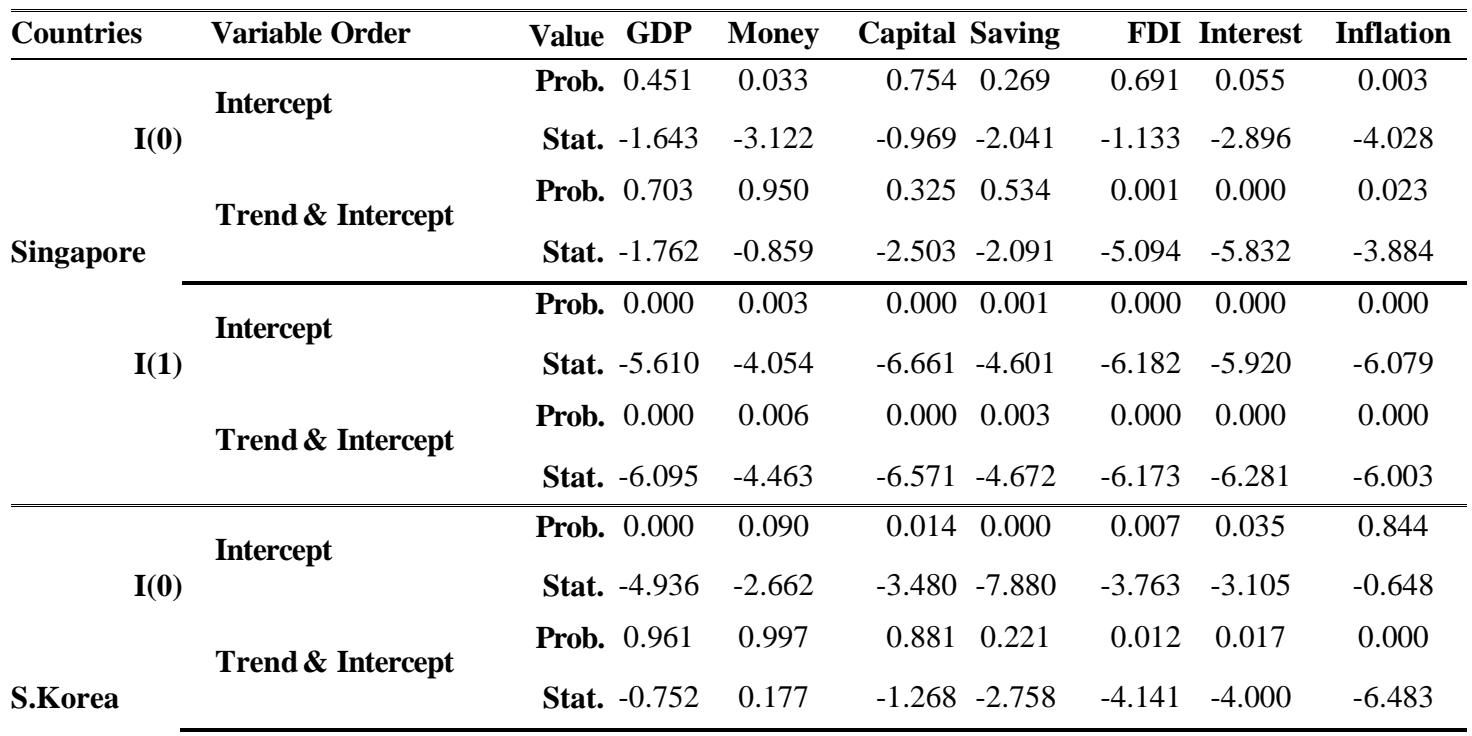




\begin{tabular}{|c|c|c|c|c|c|c|c|c|}
\hline \multirow{4}{*}{$\mathbf{I}(\mathbf{1})$} & \multirow{2}{*}{ Intercept } & Prob. 0.002 & 0.005 & 0.000 & 0.068 & 0.000 & 0.000 & 0.000 \\
\hline & & Stat. -4.172 & -3.896 & -4.858 & -2.802 & -4.991 & -5.516 & -6.792 \\
\hline & \multirow{2}{*}{ Trend \& Intercept } & Prob. 0.000 & 0.007 & 0.000 & 0.002 & 0.000 & 0.000 & 0.000 \\
\hline & & Stat. -6.304 & -4.359 & -5.975 & -4.957 & -5.589 & -5.535 & -6.276 \\
\hline \multirow{8}{*}{ Malaysia } & \multirow{2}{*}{ Intercept } & Prob. 0.884 & 0.671 & 0.767 & 0.654 & 0.013 & 0.801 & 0.007 \\
\hline & & Stat. -0.483 & -1.186 & -0.933 & -1.224 & -3.513 & -0.823 & -3.755 \\
\hline & \multirow{2}{*}{ Trend \& Intercept } & Prob. 0.677 & 0.308 & 0.493 & 0.931 & 0.001 & 0.084 & 0.021 \\
\hline & & Stat. -1.817 & -2.542 & -2.168 & -1.007 & -5.090 & -3.286 & -3.913 \\
\hline & \multirow{2}{*}{ Intercept } & Prob. 0.000 & 0.000 & 0.000 & 0.000 & 0.000 & 0.000 & 0.000 \\
\hline & & Stat. -5.150 & -5.796 & -5.443 & -5.897 & -6.830 & -5.531 & -5.632 \\
\hline & \multirow{2}{*}{ Trend \& Intercept } & Prob. 0.001 & 0.274 & 0.001 & 0.000 & 0.000 & 0.000 & 0.000 \\
\hline & & Stat. -5.078 & -2.621 & -5.369 & -6.165 & -6.727 & -5.414 & -5.657 \\
\hline \multirow{8}{*}{ Thailand } & \multirow{2}{*}{ Intercept } & Prob. 0.554 & 0.000 & 0.464 & 0.244 & 0.002 & 0.702 & 0.000 \\
\hline & & Stat. -1.437 & -6.835 & -1.617 & -2.105 & -4.391 & -1.109 & -5.984 \\
\hline & \multirow{2}{*}{ Trend \& Intercept } & Prob. 0.606 & 0.902 & 0.499 & 0.533 & 0.065 & 0.285 & 0.000 \\
\hline & & Stat. -1.954 & -1.171 & -2.156 & -2.092 & -3.412 & -2.594 & -5.872 \\
\hline & \multirow{2}{*}{ Intercept } & Prob. 0.016 & 0.357 & 0.001 & 0.044 & 0.000 & 0.000 & 0.000 \\
\hline & & Stat. -3.424 & -1.838 & -4.711 & -3.005 & -9.384 & -5.421 & -6.895 \\
\hline & \multirow{2}{*}{ Trend \& Intercept } & Prob. 0.047 & 0.004 & 0.003 & 0.066 & 0.001 & 0.001 & 0.000 \\
\hline & & Stat. -3.570 & -4.571 & -4.718 & -3.404 & -5.251 & -5.370 & -6.909 \\
\hline
\end{tabular}

b) Diagnostic Tests

The diagnostic tests are performed to check normality in the data, serial correlation, and heteroscedasticity test for each equation however; table 2 presents only equation 1 . They must be conducted before the use of the ARDL model to draw unbiased reliable outcomes and fulfill the requirement of the ARDL model of the study. The results of the diagnostic tests are given in Table 2(a), 2 (b) and 2 (c). All participating variables in the analysis are normally distributed according to Jarque-Bera and Probability statistics. The study applied the Breusch-Godfrey Serial Correlation LM Test to ascertain autocorrelation in the time series. The outcomes of the LM test clarified that there is no autocorrelation among the variables. The Heteroskedasticity Test: Breusch-Pagan- Godfrey is employed which reports that there is no heteroskedasticity in the series.

Table 2 (a): Normality Test

\begin{tabular}{ccc}
\hline Countries & Jarque-Bera & Proabablity \\
\hline \hline Singapore & 0.906 & 0.636 \\
S. Korea & 0.272 & 0.873 \\
Malaysia & 1.363 & 0.506 \\
Thailand & 1.874 & 0.392 \\
\hline
\end{tabular}

Table 2 (b): Serial Correlation LM Test

\begin{tabular}{ccc}
\hline Countries & F-statistic & Prob. Chi-Square \\
\hline Singapore & 1.181 & 0.137 \\
S. Korea & 0.264 & 0.581 \\
Malaysia & 0.295 & 0.625 \\
Thailand & 0.363 & 0.601 \\
\hline
\end{tabular}


Table 2 (c): Heteroskedasticity Test

\begin{tabular}{ccc}
\hline Countries & F-statistic & Prob. Chi-Square \\
\hline \hline Singapore & 0.783 & 0.579 \\
S. Korea & 1.229 & 0.306 \\
Malaysia & 1.316 & 0.259 \\
Thailand & 0.538 & 0.796 \\
\hline
\end{tabular}

c) Lag Selection Criteria

The outcomes are shown in Table 3 imply that the optimum lag order is 02 based on the AIC: Akaike information criterion. The pertinent lag order keeps away from the spuriousness of the ARDL bounds testing approach to cointegration outcomes.

Table 3: VAR Lag Selection Criteria

\begin{tabular}{cccc}
\hline Optimum Lag & Method & No. of Observation & Period \\
\hline \hline 2 & AIC: Akaike information criterion & 36 & $1980-2018$ \\
\hline
\end{tabular}

d) The Bounding Test

After finding the stationarity and optimum lag selection, the next step is to observe the long run interaction between monetary policy, FDI, Savings, Capital and Economic development. The study estimated the long run interaction through the ARDL bound test. Table 4 presents the outcomes of the ARDL bound test precisely. The value of F-statistics of the bound test is 19.80 with respect to Singapore, which is above the upper bound of critical value 3.61 at $05 \%$ level of significance. This suggests that when GDP is dependent variable and other variables consider as independent, the long run cointegration found among GDP, money supply, interest, inflation, savings, capital, and foreign direct investment.

Table 4: ARDL Bounds Test for Cointegration

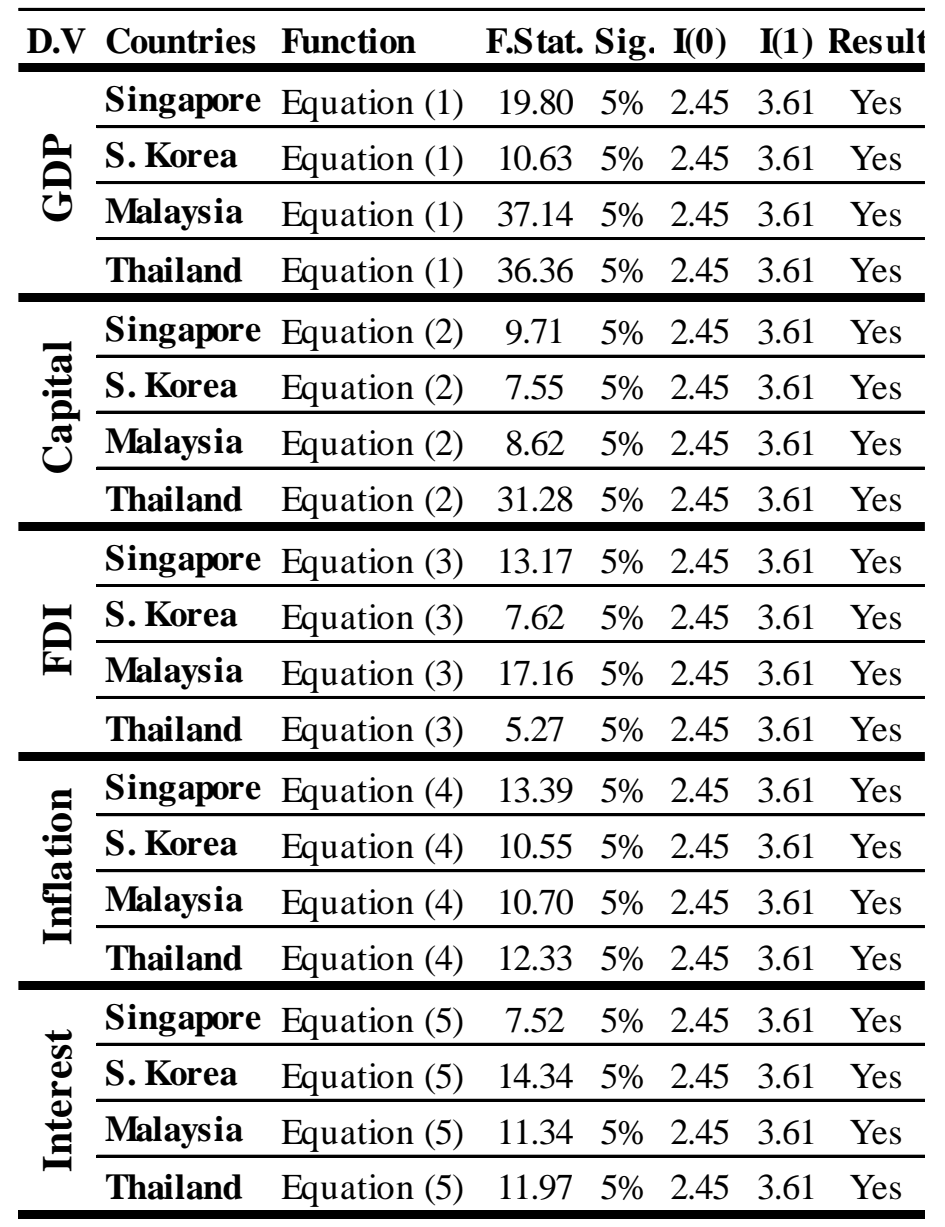




\begin{tabular}{|c|c|c|c|c|c|c|c|}
\hline \multirow{4}{*}{$\stackrel{\text { de }}{\stackrel{\theta}{0}}$} & & & 3.62 & $5 \%$ & 2.45 & 3.61 & Yes \\
\hline & & Eauntion & 6.34 & $5 \%$ & 2.45 & 3.61 & Yes \\
\hline & Mal & & 4.68 & $5 \%$ & 2.45 & 3.61 & Yes \\
\hline & & & & $5 \%$ & 2.45 & 3.61 & \\
\hline \multirow{4}{*}{ • } & & & & $5 \%$ & & 61 & \\
\hline & & & 12.46 & $5 \%$ & 2.45 & 3.61 & \\
\hline & & & 4.28 & $5 \%$ & 2.45 & 3.61 & $\mathrm{Ye}$ \\
\hline & & & 5.26 & $5 \%$ & 2.45 & 3.61 & $\mathrm{Ye}$ \\
\hline
\end{tabular}

e) ARDL Long Run Coefficient Results

The results of the long run relationships are demonstrated equation wise from table 5 to table 11 . The interpretation of the study is based on 05\% level of significance to test and explicate the relationship among variables. Table 5 revealed that capital, FDI, and savings are the most significantly related to GDP per capita prominently for middle and high-income economies with positive interaction. The coefficient of capital, FDI, and saving showed that any increase in capital, FDI, and saving would lead to a favorable output for the economies. Money supply, interest, and inflation have the insignificant effect on GDP per capita in middle and high- income economies in the long run except for Singapore but the coefficient of their determinants has a negative influence on GDP per capita in most cases. The study presented the long run results of equation (2) in table 6.

Table 5: ARDL Long Run Coefficient Results

\begin{tabular}{cccccccccc}
\hline D.V & Countries & Statistics & Function & Capital & FDI & Inflation & Interest & Money & Saving \\
\hline \multirow{2}{*}{ Singapore } & t.stat. & Equation (1) & -1.970 & 2.198 & 0.912 & -2.473 & -0.634 & 5.845 \\
\cline { 2 - 10 } & & Coef. & Equation (1) & -0.099 & 0.016 & 0.002 & -0.009 & -0.043 & 0.243 \\
\hline \multirow{2}{*}{ S. Korea } & t.stat. & Equation (1) & 1.979 & 3.353 & -1.673 & -1.663 & -1.089 & 0.044 \\
\cline { 3 - 10 } & & Coef. & Equation (1) & 0.068 & 0.371 & -0.003 & -0.007 & -0.116 & 0.005 \\
\hline \multirow{2}{*}{ Malaysia } & t.stat. & Equation (1) & 5.001 & -0.418 & 0.457 & -0.335 & 1.656 & 0.328 \\
\cline { 2 - 9 } & Coef. & Equation (1) & 0.215 & -0.002 & 0.001 & -0.001 & 0.038 & 0.020 \\
\hline & Thailand & t.stat. & Equation (1) & 5.923 & -1.230 & -1.677 & -2.041 & 0.540 & 3.909 \\
\cline { 2 - 9 } & Coef. & Equation (1) & 0.189 & -0.016 & -0.002 & -0.005 & 0.041 & 0.205 \\
\hline
\end{tabular}

Table 6: ARDL Long Run Coefficient Results

\begin{tabular}{|c|c|c|c|c|c|c|c|c|c|}
\hline$\overline{D . V}$ & Countries & Statistics & Function & GDP & FDI & Inflation & Interest & Money & Saving \\
\hline \multirow{8}{*}{ } & \multirow[t]{2}{*}{ Singapore } & t.stat. & Equation (2) & -0.967 & 0.878 & 2.939 & -0.299 & -1.346 & 3.723 \\
\hline & & Coef. & Equation (2) & -1.410 & 0.066 & 0.024 & -0.005 & -0.420 & 1.375 \\
\hline & \multirow[t]{2}{*}{ S. Korea } & t.stat. & Equation (2) & 3.520 & -2.621 & 2.678 & 0.585 & 0.946 & 0.611 \\
\hline & & Coef. & Equation (2) & 2.314 & -0.123 & 0.010 & 0.004 & 0.165 & 0.158 \\
\hline & \multirow[t]{2}{*}{ Malaysia } & t.stat. & Equation (2) & 7.426 & 2.803 & 1.010 & -2.755 & -0.760 & -0.622 \\
\hline & & Coef. & Equation (2) & 4.281 & 0.048 & 0.007 & -0.031 & -0.061 & -0.081 \\
\hline & \multirow[t]{2}{*}{ Thailand } & t.stat. & Equation (2) & 8.185 & 0.324 & 3.382 & 0.215 & 1.717 & -2.468 \\
\hline & & Coef. & Equation (2) & 3.718 & 0.005 & 0.008 & 0.001 & 0.318 & -0.454 \\
\hline
\end{tabular}

The results indicated that GDP and inflation are most significant toward Capital with a positive association. Moreover, FDI inflow and Saving affect the significantly gross Capital formation of Malaysia and
South Korea while the coefficient of FDI inflow has a positive and negative impact on the Capital of both countries respectively. The outcome of table 7 suggests that any increase in the lending Interest rate in South 
Korea and Malaysia would lead to an appreciation in FDI. In the meantime, GDP and Capital have been affecting the FDI significantly in Singapore, South Korea, and Malaysia. Table 8 explains the result of equation (4) in which Inflation is taken as the dependent variable.
Saving has a much greater influence on Inflation than other explanatory variables. Capital, Interest, and FDI behave significantly in different countries, however, Thailand and Singapore are the most affected countries in terms of inflation by their explanatory variables.

Table 7: ARDL Long Run Coefficient Results

\begin{tabular}{rrrrrrrrr}
\hline D.V Countries & Statistics & Function & GDP & Capital & Inflation & Interest & Money & Saving \\
\hline \multirow{2}{*}{ Singapore } & t.stat. & Equation (3) & 2.399 & -0.877 & -0.664 & 1.834 & 0.992 & -0.708 \\
\cline { 2 - 9 } & Coef. & Equation (3) & 7.064 & -0.305 & -0.009 & 0.072 & 0.783 & -0.592 \\
\hline \multirow{2}{*}{ S. Korea } & t.stat. & Equation (3) & 0.913 & -2.577 & 1.090 & 2.288 & 1.378 & 1.751 \\
\cline { 3 - 9 } & Coef. & Equation (3) & 4.344 & -3.045 & 0.018 & 0.072 & 1.093 & 2.215 \\
\hline \multirow{2}{*}{ Malaysia } & t.stat. & Equation (3) & -2.084 & 3.405 & 1.258 & 3.403 & 0.007 & 0.665 \\
\cline { 2 - 9 } & Coef. & Equation (3) & -13.096 & 3.625 & 0.026 & 0.217 & 0.003 & 0.507 \\
\hline \multirow{2}{*}{ Thailand } & t.stat. & Equation (3) & -1.573 & 1.247 & 1.052 & -0.577 & 0.928 & 1.143 \\
\cline { 2 - 9 } & Coef. & Equation (3) & -9.880 & 1.910 & 0.025 & -0.019 & 1.262 & 1.702 \\
\hline
\end{tabular}

According to the results of table 8, Saving, Capital, Interest have a significant effect on FDI in participating countries of the study. Thailand and
Singapore are one of them where mostly explanatory variables such as GDP, Capital, Interest, and Saving play a meaningful role in overcoming Inflation.

Table 8: ARDL Long Run Coefficient Results

\begin{tabular}{|c|c|c|c|c|c|c|c|c|c|}
\hline D.V & Countries & Statistics & Function & GDP & Capital & FDI & Interest & Money & Saving \\
\hline \multirow{8}{*}{ 苞 } & \multirow{2}{*}{ Singapore } & t.stat. & Equation (4) & 1.855 & 3.063 & -0.978 & 2.280 & 1.875 & -2.938 \\
\hline & & Coef. & Equation (4) & 60.670 & 10.514 & -0.975 & 0.832 & 15.191 & -22.479 \\
\hline & \multirow{2}{*}{ S. Korea } & t.stat. & Equation (4) & -0.186 & 1.502 & 0.994 & 4.360 & 1.025 & -1.369 \\
\hline & & Coef. & Equation (4) & -13.827 & 25.954 & 2.261 & 1.600 & 9.658 & -27.945 \\
\hline & \multirow[t]{2}{*}{ Malaysia } & t.stat. & Equation (4) & 0.729 & -0.923 & 2.093 & -0.867 & -0.753 & 2.529 \\
\hline & & Coef. & Equation (4) & 46.074 & -12.188 & 3.747 & -0.616 & -3.897 & 16.355 \\
\hline & \multirow{2}{*}{ Thailand } & t.stat. & Equation (4) & -2.171 & 2.785 & 0.703 & -1.490 & -0.727 & 2.795 \\
\hline & & Coef. & Equation (4) & -106.653 & 24.502 & 0.680 & -0.637 & -9.072 & 30.327 \\
\hline
\end{tabular}

Table 9 presents the result of equation (5) when the study took interest as the dependent variable. In this case, FDI and Saving stimulate and surge lending interest rates. Meanwhile, GPD has a significant and inverse impact on Interest in Singapore while it is positively and significantly associated with Interest in Thailand. South Korea's money supply is influenced by defining indicators according to equation (6) and table 10 as compare to other economies. The table 11 indicates that an increase in GDP per capita and Inflation would lead to Saving in middle and highincome economies except for Singapore because the rise in Inflation would create trouble for Saving in Singapore's economy.

Table 9: ARDL Long Run Coefficient Results

\begin{tabular}{|c|c|c|c|c|c|c|c|c|c|}
\hline D.V & Countries & Statistics & Function & GDP & Capital & FDI & Inflation & Money & Saving \\
\hline \multirow{4}{*}{ 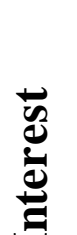 } & \multirow[t]{2}{*}{ Singapore } & t.stat. & Equation (5) & -2.609 & 0.020 & 0.784 & 1.597 & -0.025 & 2.609 \\
\hline & & Coef. & Equation (5) & -31.098 & 0.036 & 0.372 & 0.105 & -0.097 & 9.767 \\
\hline & \multirow[t]{2}{*}{ S. Korea } & t.stat. & Equation (5) & 0.565 & 1.829 & 2.934 & 0.355 & -3.599 & -1.806 \\
\hline & & Coef. & Equation (5) & 20.120 & 18.209 & 4.704 & 0.040 & -19.612 & -19.139 \\
\hline
\end{tabular}




\begin{tabular}{ccccccccc}
\hline \multirow{2}{*}{ Malaysia } & t.stat. & Equation (5) & -0.862 & 0.903 & 2.427 & -0.436 & -1.865 & -0.038 \\
\cline { 2 - 9 } & Coef. & Equation (5) & -3.817 & 0.563 & 50.684 & -0.041 & -5.963 & -0.085 \\
\hline \multirow{2}{*}{ Thailand } & t.stat. & Equation (5) & 2.073 & 0.710 & -1.944 & 1.089 & -0.374 & 1.459 \\
\cline { 2 - 9 } & Coef. & Equation (5) & 14.321 & 0.425 & -55.348 & 0.102 & -3.040 & 15.161 \\
\hline
\end{tabular}

Table 10: ARDL Long Run Coefficient Results

\begin{tabular}{|c|c|c|c|c|c|c|c|c|c|}
\hline D.V & Countries & Statistics & Function & GDP & Capital & FDI & Inflation & Interest & Saving \\
\hline \multirow{6}{*}{$\frac{\vec{\theta}}{2}$} & \multirow[t]{2}{*}{ Singapore } & t.stat. & Equation (6) & -1.655 & 1.487 & -1.916 & 1.729 & -0.870 & 2.467 \\
\hline & & Coef. & Equation (6) & -0.464 & 0.055 & -2.236 & 0.018 & -0.013 & 0.950 \\
\hline & \multirow[t]{2}{*}{ S. Korea } & t.stat. & Equation (6) & -0.589 & 2.307 & 3.717 & 0.979 & -3.597 & -3.949 \\
\hline & & Coef. & Equation (6) & -0.206 & 0.135 & 4.788 & 0.004 & -0.026 & -1.428 \\
\hline & \multirow[t]{2}{*}{ Malaysia } & t.stat. & Equation (6) & 0.443 & -0.019 & 1.276 & -1.241 & 0.109 & 0.141 \\
\hline & & Coef. & Equation (6) & 0.005 & 0.000 & 1.766 & -0.342 & 0.002 & 0.034 \\
\hline
\end{tabular}

Table 11: ARDL Long Run Coefficient Results

\begin{tabular}{|c|c|c|c|c|c|c|c|c|c|}
\hline D.V & Countries & Statistics & Function & GDP & Capital & FDI & Inflation & Interest & Money \\
\hline \multirow{8}{*}{ 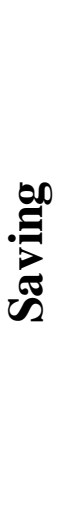 } & \multirow[t]{2}{*}{ Singapore } & t.stat. & Equation (7) & 6.146 & 2.888 & -0.806 & 6.146 & 2.131 & 1.705 \\
\hline & & Coef. & Equation (7) & 2.772 & 0.342 & -0.017 & -0.006 & 0.015 & 0.285 \\
\hline & \multirow[t]{2}{*}{ Malaysia } & t.stat. & Equation (7) & 1.457 & -0.255 & 0.967 & 2.601 & 1.381 & 1.566 \\
\hline & & Coef. & Equation (7) & 1.206 & -0.047 & 0.015 & 0.010 & 0.014 & 0.188 \\
\hline & \multirow[t]{2}{*}{ S. Korea } & t.stat. & Equation (7) & 5.258 & -1.206 & 0.184 & 0.613 & -0.216 & -2.577 \\
\hline & & Coef. & Equation (7) & 2.934 & -0.214 & 0.004 & 0.002 & -0.001 & -0.225 \\
\hline & \multirow[t]{2}{*}{ Thailand } & t.stat. & Equation (7) & 3.673 & -2.127 & -1.019 & 2.441 & 1.010 & 2.034 \\
\hline & & Coef. & Equation (7) & 2.679 & -0.442 & -0.018 & 0.010 & 0.007 & 0.404 \\
\hline
\end{tabular}

\section{f) ECM Model}

CM (Error Correction Model) is applied to probe the short run interaction related to the long run relationship between the variables. The results of the ECM model for each equation are described in Table 12 but the study would like to interpret only equation (1) with respect to Singapore at 05\% level of significance. The outcomes are described in table 12 express that the coefficient of ECM is $=-0.87$ for Singapore's economy and it is significant. The sign of the coefficient of ECM is negative and its probability value is " 0 " which ratifies the significant, strong and the long run relationship between GDP per capita and explanatory variables. The RSquare explained that defining variables have 95\% control aggregately on the GDP of Singapore and they have a significant impact cumulatively on GDP per capita in Singapore.

Table 12: Error Correction Model Summary

\begin{tabular}{clllcccccc}
\hline & Countries & ECM & Coef. & t-Stat. & P-Value & $\mathbf{R}^{\mathbf{2}}$ & Adj. $\mathbf{R}^{\mathbf{2}}$ & F. Stat. & Prob. F.Stat \\
\hline 守 & Singapore & ECT $_{\mathrm{t}-1}$ & -0.87 & -13.35 & 0.00 & 0.95 & 0.94 & 68.30 & 0.00 \\
\cline { 2 - 9 } & S. Korea & ECT $_{\mathrm{t}-1}$ & -0.39 & -9.89 & 0.00 & 0.98 & 0.97 & 113.68 & 0.00 \\
\cline { 2 - 9 } & Malaysia & ECT $_{\mathrm{t}-1}$ & -0.86 & -14.95 & 0.00 & 0.93 & 0.91 & 76.20 & 0.00 \\
\hline Thailand & ECT $_{\mathrm{t}-1}$ & -0.70 & -18.30 & 0.00 & 0.95 & 0.93 & 49.33 & 0.00 \\
\hline
\end{tabular}




\begin{tabular}{|c|c|c|c|c|c|c|c|c|c|}
\hline \multirow{4}{*}{ 胥 } & Singapore & $\mathrm{ECT}_{\mathrm{t}-1}$ & -1.18 & -9.30 & 0.00 & 0.87 & 0.84 & 26.83 & 0.00 \\
\hline & S. Korea & $\mathrm{ECT}_{\mathrm{t}-1}$ & -0.82 & -8.39 & 0.00 & 0.96 & 0.94 & 53.64 & 0.00 \\
\hline & Malaysia & $\mathrm{ECT}_{\mathrm{t}-1}$ & -0.96 & -8.68 & 0.00 & 0.95 & 0.94 & 120.36 & 0.00 \\
\hline & Thailand & $\mathrm{ECT}_{\mathrm{t}-1}$ & -1.32 & -16.36 & 0.00 & 0.91 & 0.90 & 159.01 & 0.00 \\
\hline \multirow{4}{*}{ 문 } & Singapore & $\mathrm{ECT}_{\mathrm{t}-1}$ & -1.72 & -10.65 & 0.00 & 0.84 & 0.82 & 54.56 & 0.00 \\
\hline & S. Korea & $\mathrm{ECT}_{\mathrm{t}-1}$ & -1.36 & -8.28 & 0.00 & 0.76 & 0.70 & 10.98 & 0.00 \\
\hline & Malaysia & $\mathrm{ECT}_{\mathrm{t}-1}$ & -1.61 & -12.20 & 0.00 & 0.93 & 0.92 & 106.06 & 0.00 \\
\hline & Thailand & $\mathrm{ECT}_{\mathrm{t}-1}$ & -1.76 & -6.93 & 0.00 & 0.86 & 0.82 & 18.48 & 0.00 \\
\hline \multirow{4}{*}{$\frac{\frac{c}{0}}{\frac{\pi}{\pi}}$} & Singapore & $\mathrm{ECT}_{\mathrm{t}-1}$ & -1.24 & -10.78 & 0.00 & 0.87 & 0.86 & 52.73 & 0.00 \\
\hline & S. Korea & $\mathrm{ECT}_{\mathrm{t}-1}$ & -0.92 & -9.50 & 0.00 & 0.79 & 0.78 & 42.58 & 0.00 \\
\hline & Malaysia & $\mathrm{ECT}_{\mathrm{t}-1}$ & -1.08 & -9.87 & 0.00 & 0.89 & 0.85 & 23.26 & 0.00 \\
\hline & Thailand & $\mathrm{ECT}_{\mathrm{t}-1}$ & -1.01 & -10.43 & 0.00 & 0.92 & 0.90 & 54.66 & 0.00 \\
\hline \multirow{4}{*}{ 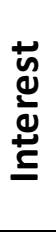 } & Singapore & $\mathrm{ECT}_{\mathrm{t}-1}$ & -1.18 & -8.02 & 0.00 & 0.72 & 0.71 & 42.93 & 0.00 \\
\hline & S. Korea & $\mathrm{ECT}_{\mathrm{t}-1}$ & -0.93 & -0.93 & 0.00 & 0.95 & 0.93 & 45.82 & 0.00 \\
\hline & Malaysia & $\mathrm{ECT}_{\mathrm{t}-1}$ & -1.09 & -10.16 & 0.00 & 0.90 & 0.87 & 26.70 & 0.00 \\
\hline & Thailand & $\mathrm{ECT}_{\mathrm{t}-1}$ & -1.13 & -10.23 & 0.00 & 0.82 & 0.79 & 28.04 & 0.00 \\
\hline \multirow{3}{*}{$\begin{array}{l}\text { d } \\
\text { ¿ } \\
\Sigma\end{array}$} & Singapore & $\mathrm{ECT}_{\mathrm{t}-1}$ & -0.59 & -5.65 & 0.00 & 0.63 & 0.55 & 8.07 & 0.00 \\
\hline & S. Korea & $\mathrm{ECT}_{\mathrm{t}-1}$ & -1.23 & -7.64 & 0.00 & 0.77 & 0.68 & 8.46 & 0.00 \\
\hline & Malaysia & $\mathrm{ECT}_{\mathrm{t}-1}$ & -1.30 & -6.33 & 0.00 & 0.60 & 0.57 & 24.49 & 0.00 \\
\hline \multirow{4}{*}{ 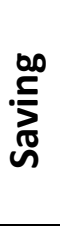 } & Singapore & $\mathrm{ECT}_{\mathrm{t}-1}$ & -0.97 & -14.47 & 0.00 & 0.89 & 0.88 & 85.35 & 0.00 \\
\hline & S. Korea & $\mathrm{ECT}_{\mathrm{t}-1}$ & -1.03 & -6.12 & 0.00 & 0.76 & 0.73 & 19.50 & 0.00 \\
\hline & Malaysia & $\mathrm{ECT}_{\mathrm{t}-1}$ & -1.23 & -10.44 & 0.00 & 0.82 & 0.79 & 27.73 & 0.00 \\
\hline & Thailand & $\mathrm{ECT}_{\mathrm{t}-1}$ & -0.91 & -6.85 & 0.00 & 0.75 & 0.68 & 11.84 & 0.00 \\
\hline
\end{tabular}

\section{g) Causation Results}

The study estimated statistical causal and directional relationships by applying the Granger Causality Test. The pairwise outcomes of the Granger Causality are presented in Table 13. The estimated outcomes reported that bidirectional causality and twoway causal relationship exist between GDP to Inflation, Interest to Capital, and Saving to Interest in Singapore, Malaysia, and Thailand respectively. There is one way, and unidirectional Granger causation exists from GDP to Inflation, from GDP to Interest, from Saving to GDP, from Interest to Capital, from Saving to Capital in South Korea, and Thailand. Meanwhile, the results also ratified that GDP leads to Capital, Interest, Inflation, and Money supply in Malaysia and Thailand. There is a one-way causal relationship running from Capital to FDI, Saving to FDI and Money in Thailand. In addition, Money and Saving would lead to Capital in Singapore. There is one way Granger Causality exists in Malaysia and South Korea with respect to Inflation to Capital and vice versa respectively.

\section{Conclusion}

The empirical finding of the study on ARDL Bound testing form, Error Correction Model (ECM) form and Granger Causality test can be concluded as follows: (1) GDP per capita and Gross Savings are highly effective and advantageous to determine other variables and contribute a significant role in most equations. In the meantime, the behavioral trend of the Money supply is statistically significant with Saving and Interest only in South Korea. (2) Gross Capital formation is another crucial indicator to provide favorable and decisive outcomes, that illuminate GPD per capita, FDI, and Savings significantly in different countries but it also surges money supply and inflation in countries like Singapore and Thailand. (3) Inflation, FDI, and lending Interest rate playing a detrimental and affirmative role toward other variables because these variables significantly related to other variables in the long run perspective. (4) There is a momentous relationship exist 
between variables in high-income economies such as Singapore and South Korea. Therefore, the economic output of high-income economies could be spoiled through the combination of determinants. (5) The economic output could be worse in middle-income economies in response to fluctuations in economic indicators but it would be less harmful as compared to high-income economies.

In addition, the study measures a directional and causal relationship with the help of the Granger Causality test. The causation result described that most of the explanatory variable has one way and unidirectional effect on others variable such as GDP versus Interest, Saving versus Capital, Inflation versus
Capital and etc. but some of them have two way and bidirectional causation on other variables.

The study deduced that economic variables make the utmost uncertainties during the long run toward economic output; however, some of them have the least impact on economic activities in middle and high-income economies like money supply. Therefore, if policymakers like to boost economic output then they have to focus on gross capital formation, gross savings and GDP per capita to get better economic output. Moreover, the government should formulate effective and fruitful policies to tackle economic issues to make less severe in the long run.

Table 13: Pairwise Granger Causality Tests

\begin{tabular}{|c|c|c|c|c|c|c|c|c|}
\hline \multirow[t]{2}{*}{ Variables } & \multicolumn{2}{|c|}{ Singapore } & \multicolumn{2}{|c|}{ S. Korea } & \multicolumn{2}{|c|}{ Malaysia } & \multicolumn{2}{|c|}{ Thailand } \\
\hline & F-Stat. & Prob. & F-Stat. & Prob. & F-Stat. & Prob. & F-Stat. & Prob. \\
\hline CAPITAL does not Granger Cause GDP & 2.12 & 0.14 & 0.76 & 0.48 & 3.09 & 0.06 & 2.41 & 0.11 \\
\hline GDP does not Granger Cause CAPITAL & 0.98 & 0.39 & 0.95 & 0.40 & 3.77 & 0.03 & 8.40 & 0.00 \\
\hline FDI does not Granger Cause GDP & 1.86 & 0.17 & 1.83 & 0.18 & 0.14 & 0.87 & 0.74 & 0.48 \\
\hline GDP does not Granger Cause FDI & 1.01 & 0.38 & 0.14 & 0.87 & 0.06 & 0.94 & 1.77 & 0.19 \\
\hline INFLATION does not Granger Cause GDP & 5.78 & 0.01 & 1.22 & 0.31 & 1.52 & 0.23 & 1.26 & 0.30 \\
\hline GDP does not Granger Cause INFLATION & 4.25 & 0.02 & 4.71 & 0.02 & 0.52 & 0.60 & 4.24 & 0.02 \\
\hline INTEREST does not Granger Cause GDP & 1.37 & 0.27 & 1.53 & 0.23 & 0.83 & 0.45 & 1.07 & 0.36 \\
\hline GDP does not Granger Cause INTEREST & 2.16 & 0.13 & 8.22 & 0.00 & 13.30 & 0.00 & 4.92 & 0.01 \\
\hline MONEY does not Granger Cause GDP & 2.81 & 0.08 & 2.08 & 0.14 & 0.07 & 0.93 & 0.49 & 0.62 \\
\hline GDP does not Granger Cause MONEY & 1.57 & 0.22 & 1.76 & 0.19 & 0.14 & 0.87 & 3.73 & 0.04 \\
\hline SAVING does not Granger Cause GDP & 0.24 & 0.79 & 3.33 & 0.05 & 0.15 & 0.86 & 3.31 & 0.05 \\
\hline GDP does not Granger Cause SAVING & 0.10 & 0.90 & 0.07 & 0.93 & 0.20 & 0.82 & 0.83 & 0.45 \\
\hline FDI does not Granger Cause CAPITAL & 2.64 & 0.09 & 0.23 & 0.80 & 0.43 & 0.65 & 0.15 & 0.86 \\
\hline CAPITAL does not Granger Cause FDI & 0.62 & 0.55 & 0.02 & 0.99 & 0.29 & 0.75 & 3.20 & 0.05 \\
\hline INFLATIONdoes notGrangerCauseCAPITAL & 0.00 & 1.00 & 0.27 & 0.76 & 4.84 & 0.01 & 1.89 & 0.17 \\
\hline CAPITALdoes not GrangerCause INFLATION & 0.63 & 0.54 & 4.34 & 0.02 & 1.66 & 0.21 & 2.90 & 0.07 \\
\hline INTEREST does not Granger Cause CAPITAL & 0.52 & 0.60 & 0.59 & 0.56 & 5.87 & 0.01 & 1.96 & 0.16 \\
\hline CAPITAL does not Granger Cause INTEREST & 1.81 & 0.18 & 7.22 & 0.00 & 7.59 & 0.00 & 6.79 & 0.00 \\
\hline MONEY does not Granger Cause CAPITAL & 4.37 & 0.02 & 1.05 & 0.36 & 0.08 & 0.93 & 0.09 & 0.91 \\
\hline CAPITAL does not Granger Cause MONEY & 1.37 & 0.27 & 0.55 & 0.58 & 0.02 & 0.98 & 2.29 & 0.12 \\
\hline SAVING does not Granger Cause CAPITAL & 3.68 & 0.04 & 3.25 & 0.05 & 0.04 & 0.96 & 5.44 & 0.01 \\
\hline CAPITAL does not Granger Cause SAVING & 0.20 & 0.82 & 0.04 & 0.96 & 0.04 & 0.96 & 0.21 & 0.81 \\
\hline INFLATION does not Granger Cause FDI & 0.11 & 0.90 & 0.83 & 0.45 & 2.51 & 0.10 & 1.35 & 0.27 \\
\hline FDI does not Granger Cause INFLATION & 2.85 & 0.07 & 0.59 & 0.56 & 0.60 & 0.56 & 0.06 & 0.94 \\
\hline INTEREST does not Granger Cause FDI & 0.68 & 0.51 & 0.53 & 0.59 & 0.04 & 0.96 & 0.11 & 0.90 \\
\hline FDI does not Granger Cause INTEREST & 0.74 & 0.49 & 0.53 & 0.59 & 0.34 & 0.71 & 0.33 & 0.72 \\
\hline MONEY does not Granger Cause FDI & 1.81 & 0.18 & 0.17 & 0.84 & 0.43 & 0.65 & 0.69 & 0.51 \\
\hline FDI does not Granger Cause MONEY & 0.11 & 0.90 & 1.60 & 0.22 & 0.04 & 0.96 & 0.04 & 0.96 \\
\hline SAVING does not Granger Cause FDI & 1.14 & 0.33 & 2.45 & 0.10 & 0.39 & 0.68 & 3.28 & 0.05 \\
\hline FDI does not Granger Cause SAVING & 2.20 & 0.13 & 3.09 & 0.06 & 0.09 & 0.92 & 0.11 & 0.90 \\
\hline INTEREST does not Granger Cause INFLATION & 0.97 & 0.39 & 0.51 & 0.60 & 0.37 & 0.70 & 2.48 & 0.10 \\
\hline
\end{tabular}




\begin{tabular}{lllllllll} 
INFLATION does not Granger Cause INTEREST & 0.64 & 0.54 & 0.27 & 0.76 & 0.77 & 0.47 & 0.14 & 0.87 \\
\hline MONEYdoes not GrangerCause INFLATION & 0.60 & 0.56 & 1.12 & 0.34 & 1.26 & 0.30 & 0.62 & 0.55 \\
INFLATIONdoes not GrangerCause MONEY & 0.28 & 0.76 & 1.51 & 0.24 & 0.67 & 0.52 & 1.44 & 0.25 \\
\hline SAVINGdoes not GrangerCause INFLATION & 3.12 & 0.06 & 0.83 & 0.45 & 0.17 & 0.84 & 1.50 & 0.24 \\
INFLATIONdoes not GrangerCause SAVING & 1.90 & 0.17 & 2.82 & 0.07 & 1.08 & 0.35 & 1.42 & 0.26 \\
\hline MONEY does not Granger Cause INTEREST & 0.09 & 0.92 & 0.94 & 0.40 & 0.67 & 0.52 & 1.02 & 0.37 \\
INTEREST does not Granger Cause MONEY & 0.44 & 0.65 & 1.04 & 0.37 & 0.60 & 0.56 & 1.62 & 0.21 \\
\hline SAVING does not Granger Cause INTEREST & 1.66 & 0.21 & 1.46 & 0.25 & 0.72 & 0.50 & 7.28 & 0.00 \\
INTEREST does not Granger Cause SAVING & 1.05 & 0.36 & 1.71 & 0.20 & 1.21 & 0.31 & 3.42 & 0.05 \\
\hline SAVING does not Granger Cause MONEY & 1.93 & 0.16 & 0.03 & 0.97 & 0.55 & 0.58 & 5.73 & 0.01 \\
MONEY does not Granger Cause SAVING & 2.88 & 0.07 & 1.10 & 0.34 & 0.69 & 0.51 & 0.07 & 0.94 \\
\hline
\end{tabular}

References Références Referencias

1. Aslam, A.M., 2016. Impact of Money Supply on Sri Lankan Economy: An Econometric Analysis. International Letters of Social and Humanistic Sciences 67, 11-17.

2. Akram, N., Akram, M.I., 2015. Savings Behaviour in Muslim and Non-Muslim Countries in Context to the Interest Rate. Pakistan Journal of Applied Economics 25, 161-177.

3. Alvi, A.A., Fatima, A., 2017. Domestic Saving under the Perspective of Interest Rate, unemployment and inflation in Pakistan: A Time Series Analysis. Bulletin of Business and Economics 6, 15-27.

4. Anwar, A., Mohsin, A.Q., Saboor, A., 2016. Impact of Monetary Policy on Economic Growth in Pakistan: Evaluation and Analysis. Pakistan Journal of Social Sciences (PJSS) 36, 131-140.

5. Ayyoub, M., Chaudhry, I.S., Farooq, F., 2011. Does Inflation Affect Economic Growth? The case of Pakistan. Pakistan Journal of Social Sciences (PJSS) 31, 51-64.

6. Belascu, L., Horobet, A., 2015. Foreign Direct Investments and Institutional Performance: A Romanian Perspective. Bulletin of Taras Shevchenko National University of Kyiv. Economics 9, 21-26.

7. Belloumi, M., Alshehry, A., 2018. The Impacts of Domestic and Foreign Direct Investments on Economic Growth in Saudi Arabia. Economies 6, 1-17.

8. Bhat, S.A., Laskar, M.R., 2016. Interest Rate, Inflation Rate and Gross Domestic Product of India. International Journal of Technical Research \& Science1, 284-288.

9. Bukowski, S.I., Bukowska, J.E., 2017. Changes of Money Supply, Interest Rates, Foreign Exchange and Economic Growth in the Euro Area. Acta Universitatis Lodziensis. Folia Oeconomica 6, 159-173.

10. Castro, P.G., Fernandes, E.A., Campos, A.C., 2013. The determinants of foreign direct investment in Brazil and Mexico: an empirical analysis. Procedia Economics and Finance 5, 231-240.
11. Carbonell, J.B., Werner, R.A., 2018. Does Foreign Direct Investment Generate Economic Growth? A New Empirical Approach Applied to Spain. Economic Geography 94, 425-456.

12. Celik, B., Usoro, A., Yakubu, A., 2019. Effects of an Unchanged Monetary Policy Rate in Nigeria's Economic Growth. Nile Journal of Business and Economics 11, 59-68

13. Chaitip, P., Chokethaworn, K., Chaiboonsri, C., Khounkhalax, M., 2015. Money Supply Influencing on Economic Growth-wide Phenomena of AEC Open Region. Procedia Economics and Finance 24, 105-115.

14. Chang, T., Li, X.L., Jiang, C., 2014. Money Growth and Inflation in China: New Evidence from a Wavelet Analysis. International Review of Economics \& Finance 35, 249-261.

15. Comes, C.A., Bunduchi, E., Vasile, V., Stefan, D., 2018. The Impact of Foreign Direct Investments and Remittances on Economic Growth: A Case Study in Central and Eastern Europe. Sustainability 10, 1-16.

16. Denbel, F.S., Ayen, Y.W., Regasa, T.A., 2016. The Relationship between Inflation, Money Supply and Economic Growth in Ethiopia: Co integration and Causality Analysis. International Journal of Scientific and Research Publications 6, 556-565.

17. Dkhili, H., Dhiab, L.B., 2018. The Relationship between Economic Freedom and FDI versus Economic Growth: Evidence from the GCC Countries. Journal of Risk and Financial Management 11, 1-17.

18. Galadima, M.D., Ngada, M.H., 2017. Impact of Money Supply on Economic Growth in Nigeria. Dutse Journal of Economics \& Development Studies 3, 133-144.

19. Handa, J., 2009. Monetary Economics, Taylor \& Francis e-Library 2, 1-842.

20. Hussain, M.I., Zafar, T., 2018. The Interrelationship between Money Supply, Inflation, Public Expenditure and Economic Growth. European Online Journal of Natural and Social Sciences 7, 1-24

21. Jednak, S., Kragulj, D., 2018. The Relationship between Economic Growth and Inflation: The Case 
of Poland and Serbia. Zeszyty Naukowe Pwsz W Płocku. Nauki Ekonomiczne 28, 95- 108.

22. Lee, K.S., Werner, R.A., 2018. Reconsidering Monetary Policy: An Empirical Examination of the Relationship between Interest Rates and Nominal GDP Growth in the U.S., U.K., Germany and Japan. Ecological Economics 146, 26-34.

23. Lloyd, R.A., 2017. The Panama Canal as a Determinant of FDI in Panama. Review of Integrative Business and Economics Research 7, 87-102.

24. Mansoor, A., Shoukat, Q., Bibi, S., Iqbal, K., Saeed, R., Zaman, K., 2018. The Relationship between Money Supply, Price Level and Economic Growth in Pakistan: Keynesian versus Monetarist View. Review of Economic and Business Studies 11, 49-64.

25. Mansur, K., 2011. Savings, Investment \& FDI Contribution to Malaysian Economic Growth in the Globalization Era. International Business \& Economics Research Journal 2, 1-14.

26. Mele, A., Stefanski, R., 2019. Velocity in the LongRun: Money and Structural Transformation. Review of Economic Dynamics 31, 393-410.

27. Measuring Capital: OECD Manual 2009.

28. Mlosa, C., Hakim, L., Rahayu, S.A., 2018. The Role of Credit, Money, and Exchange Rate Channels on Monetary Transmission Mechanism in Five East Africa Community (EAC) Countries. Advances in Social Science, Education and Humanities Research 292, 310-315.

29. Morteza, E., Farahani, Y.G., 2016. The Relationship between Money Supply and Economic Activity in Countries Dependent on Natural Resources. Journal of Economics and Sustainable Development 7, 21-29.

30. Mousavi, N., Monjazeb, M., 2014. The Impact of Growth Rate of Real GDP Per Capita on the Savings Rate in Iran and Some Developing and Developed Selected Countries. International Journal of Scientific Management and Development 2, 425-431.

31. Najarzadeh, R., Reed, M., Tasan, M., 2014. Relationship between Savings and Economic Growth: The Case for Iran. Journal of International Business and Economics 2, 107-124.

32. Nguyen, V.B., 2015. Effects of Fiscal Deficit and Money M2 Supply on Inflation: Evidence from Selected Economies of Asia. Journal of Economics, Finance and Administrative Science 20, 49-53.

33. Nizhegorodtsev, R., Goridko, N., 2015. The Impact of Money Supply on Economic Growth: Theory, Experience, Modelling. Handbook on Economics, Finance and Management Outlooks 03, 66-72.

34. Onyinye, N.G., Idenyi, O.S., Ifeyinwa, A.C., 2017. Effect of Capital Formation on Economic Growth in Nigeria. Asian Journal of Economics, Business and Accounting 5, 1-16.
35. Sahin, A., Dogan, I., 2017. Analysis of the Neutrality of Money for the US Economy. Journal of Applied Sciences 7, 365-373.

36. Sasongko, G., Huruta, A.D., 2018. Monetary Policy and the Causality between Inflation and Money Supply in Indonesia. Business: Theory and Practice 19, 80-87.

37. Shaukat, B., Zhu, Q., Khan, M.I., 2019. Real Interest Rate and Economic Growth: A Statistical Exploration for Transitory Economies. Science Direct 534.

38. Siddique, M.A., Naeem, M.M., Yaqoob, S., 2017. Impact of FDI on Economic Growth: Evidence from Pakistan. Bulletin of Business and Economics 6, 111-116.

39. Svedin, D., Stage, J., 2016. Impacts of foreign direct investment on efficiency in Swedish manufacturing. Springer Plus 5, 1-17.

40. Taspinar, N., 2014. Foreign Direct Investment, Domestic Savings, and Economic Growth: The Case of Turkey. International Journal of Economic Perspectives 8, 12-21.

41. Tiryaki, A., Ceylan, R., Erdoğan, L., 2018. Asymmetric Effects of Industrial Production, Money Supply and Exchange Rate Changes on Stock Returns in Turkey. Applied Economics 51, 1-12.

42. Tsai, S.L., Chang, T., 2018. The Comovment between Money and Economic Growth in 15 Asia Pacific Countries: Wavelet Coherency Analysis in Time Frequency Domain, Romanian Journal of Economic Forecasting 2, 63-79.

43. Turan, G., Gjergji, O., 2014. What is the Impact of Savings on Growth? The Case of a Small Open Economy (Albania). Mediterranean Journal of Social Sciences 5, 360-368.

44. Twinoburyo, E.N., Odhiambo, N.M., 2018. Monetary Policy and Economic Growth: A Review of International Literature. Journal of Central Banking Theory and Practice 2, 123-137.

45. Urbanovsky, T., 2016. Interconnection of Interest Rate, Price Level, Money Supply, and Real GDP: The Case of the Czech Republic. Procedia Social and Behavioral Sciences 220, 531-540. 